CHINESE HOLIDAY MAKERS' EXPENDITURE: IMPLICATIONS FOR MARKETING AND MANAGEMENT 


\begin{abstract}
Tourist destinations are more interested in attracting high-yield tourists and visitor expenditure has often been used as a measure of market yield. This study examined Chinese holiday travellers' expenditure in Australia with the purpose of identifying the characteristics of the high-spending segments in this market. A questionnaire was designed to collect data from departing Chinese tourists. The study concluded that Chinese holiday travellers’ total and disaggregated expenditures were associated with different sets of socio-demographic, trip characteristics and psychological factors. In particular, their total expenditure in Australia was determined by their income, age, place of residence, travel party size, length of stay and visitation to other destination. The study extended the existing literature on tourist expenditure. It also provided practical marketing and management implications for Australia.
\end{abstract}

KEYWORDS: Chinese holiday market to Australia, tourist expenditure 


\title{
CHINESE HOLIDAY MAKERS' EXPENDITURE: IMPLICATIONS FOR MARKETING AND MANAGEMENT
}

\begin{abstract}
INTRODUCTION
“Tourism demand affects all sectors of an economy” (Sinclair \& Stabler, 1997, p.15) and it is "the foundation on which all tourism-related business decisions ultimately rest” (Song \& Witt, 2000, p.1). Investigation of tourist expenditure is critical because it is an indicator of tourism demand and yield of a market. Additionally, tourists may be segmented and marketed based on their expenditure. Expenditure can be examined at a macro or micro level. Studies at the macro level are concerned with the analysis of aggregated expenditure in a destination by a market, whilst most expenditure studies at the micro level examine the important factors that affect individual tourists' expenditures on the trip. Although the two types of expenditure studies serve different purposes, the studies at the micro level have the advantage of taking into account the diversity and heterogeneity of consumer behaviours that are averaged out in macro-economic analysis. These studies also do not deviate too far from theoretical consumer behaviour frameworks (Alegre \& Pou, 2004).
\end{abstract}

A review of literature presented in this study suggested more emphases to be placed on first the investigation of individual travellers' expenditure, and second the impact of noneconomic and psychological factors on expenditure. Literature also suggests a clear insufficiency of research on Chinese outbound tourism (Chon, 2005) and the economic impact of Chinese outbound tourism (Chen, Guo, Wang \& Wang, 2005). Cai and Knutson (1998) and Cai, Hu, and Feng (2001) modeled the demand of Chinese for domestic tourism and Qu and Lam (1997) analysed their cross border travel demand to Hong Kong. All these studies used aggregated data. Understanding Chinese travellers’ expenditure during long haul 
international travel at the individual tourist level remains an under-researched area. The purpose of this study is to fill this knowledge gap by offering an analysis into the expenditure of Chinese travellers to Australia. More specifically, this study investigates firstly Chinese holiday travellers' spending pattern in Australia, secondly the determining factors of their expenditure, thirdly the impact of satisfaction on expenditure, and fourthly the associated managerial and marketing implications. The paper reviewed the existing research on tourist expenditure, as well as its relationships with visitor satisfaction and destination marketing. A questionnaire designed based upon the literature was used to collect Chinese traveller's social demographics, trip characteristics, satisfaction with the trip, and expenditures on various travel related goods and services in Australia. A number of bivariate and multivariate analytical techniques were used to examine Chinese travellers spending patterns in Australia and how their expenditures were affected by the economic, social-demographic and psychological factors. The study suggested that an expenditure-based segmentation of the Chinese holiday market to Australia may be feasible and a number of implications are provided for Australian destination marketers and managers.

\section{A REVIEW OF STUDIES ON TOURIST EXPENDITURE}

Understanding tourist expenditure is critically important in measuring tourism’s economic impact on the destination because tourism is an expenditure-driven economic activity (Frechtling, 2006). Expenditure studies relevant to this research may be classified into two groups. One group of studies were carried out by tourism economists who focused on modelling individual travellers' expenditure. Another group of studies explored the usefulness of expenditure as a market segmentation variable. Such a segmenting method can help maximizing the economic benefit for tourist destinations. Additionally, satisfaction may also influence the level of expenditure. The follow literature review is organised into three 
sub-sections: expenditure-based market segmentation, micro-economic modelling of tourist expenditure, as well as expenditure and satisfaction.

\section{Expenditure-based market segmentation}

Tourism has become a global phenomenon and its marketing is becoming more and more complex and costly. Destination promotional organisations are under increasing pressure to use a segmenting approach that is effective and efficient. Marketing research suggests that although people with high expenditure account for a disproportionately large percent of sales, they are often indistinguishable from those of lower expenditure in terms of economic and social demographic characteristics, and benefit sought. This increases the difficulty of targeting this group of people (Spotts \& Mahoney, 1991). However, more recent findings indicate the utility of expenditure-based market segmentation, as shown in Legohérel (1998), Moufakkir, Singh, Moufakkir-van der Woud, and Holecek, (2004), and Spotts and Mahoney (1991).

According to Kotler (1988) and Spotts \& Mahoney (1991) successful marketing segmentation must exhibit four basic characteristics, namely:

- Measurability (the degree to which the size and purchasing power of all segments can be measured);

- Substantiality (the degree to which the segments are large and/or profitable enough);

- Actionability (the degree to which effective programs can be formulated for attracting and serving the segments); and

- Accessibility (the degree to which the segment can be effectively reached and served).

The studies by Spotts and Mahoney (1991) and Moufakkir et al. (2004) analysed the expenditure-based market segmentation according to the above-listed characteristics and both 
studies demonstrated that such an approach holds some promise as a potential segmentation method for destinations. Spotts and Mahoney (1991) found that "heavy spenders" were more likely to be middle-income families travelling in a large travel party in which children are often present. They also stayed significantly longer and participated more heavily in recreation than "light spenders”. Legohérel (1998) found the opposite findings with regard to the high spending travellers by stating "the groups of three or more individuals that included children spent significantly less than childless couples” (p. 30). Moufakkir et al. (2004)

examined visitors' spending in a gaming destination finding that "heavy spenders” were often travelling from outside of the state, and were younger, more affluent, and more likely to stay in hotels or motels. Mok and Iverson (2000) also successfully segmented Taiwanese tourists to Guam using the expenditure criterion. Longer stay, younger age, smaller party size, and honeymooners were some of the characteristics of "heavy spenders" whilst income, marital status, gender or occupation could not be used to distinguish travellers with different levels of spending. It is evident that expenditure-based segmentation offers a solution to maximise the returns from marketing investment by targeting tourists having comparatively high expenditure (Laesser \& Crouch, 2006).

\section{Micro-economic modelling of tourist expenditure}

Comparing to studies using expenditure as the segmenting variable, micro-economic modelling of tourist expenditure provides useful information on what variables are associated with high expenditure and also on the extent to which each of the variables can influence the expenditure. However, "the majority of (tourism demand) studies have been macro-economic in nature, ...Micro-economic studies of individual or household tourism behaviour are rare” (Crouch, 1994, p. 41; Lim, 2006). An extensive literature search found the following microeconomic studies on trip expenditure: Agarwal and Yochum (1999, 2000), Asgary, De Los Santos, Vincent, \& Davila (1997), Aguilo Perez and Juaneda Sampol (2000), Cannon and 
Ford (2002), Jang, Cai, Morrison and O’Leary (2005), Downward and Lumsdon (2000, 2003, 2004), Jang, Bai, Hong, and O’Leary (2004) , Laesser and Crouch (2006), Leones, Colby, and Crandall (1998), Mak, Moncur, and Yonamine, (1977), Seiler, Hsieh, Seiler, and Hsieh (2002), Taylor, Fletcher, and Clabaugh, (1993), and Wang, Rompf, Severt and Peerapatdit (2006).

Trip expenditures have been measured in terms of total expenditure, expenditure per person per day, total party expenditure, party expenditure per day, pre-paid expenditure in the origin country, and expenditure in the destination. For package tourism destinations, it is necessary to separate expenditures incurred in the origin country from those at the destination, as did Aguilo Perez and Juaneda Sampol (2000). In order to provide more insightful implications for individual tourism-related sectors, Wang et al. (2006) disaggregated trip expenditure into six categories: lodging, meals, attractions, entertainment, shopping, and transportation. This allows the investigation into the degree to which a particular factor influences different spending categories.

Theoretically, a great variety of economic, social and psychological variables may influence tourism demand (Ryan, 2003). Most expenditure studies included income as an independent variable, which was found to be significant except in Downward and Lumsdon (2000) and Leones et al. (1998). Income was often measured as a categorical variable instead of a continuous variable. The effect of income was sometimes measured using dummy variables (e.g. Cannon \& Ford, 2002; Jang et al., 2004; Taylor et al., 1993). Only four studies attempted to examine the impact of price on expenditure by incorporating proxy variables such as relative price (Asgary et al., 1997), perception about price (Aguilo Perez \& Juaneda Sampol, 2000), lodging reservation and weekend accommodation (Agarwal \& Yochum, 2000), and airfare and staying in hotel (Mak et al, 1977). The results of these studies 
suggested a significant impact of price on expenditure. Price variable has often been omitted in cross sectional demand studies because it was assumed that all individuals being studied face identical prices. By doing this, the difference in behaviours can be explained by the difference in individuals’ characteristics (Deaton \& Muellbauer, 1980).

The expenditure is also affected by travellers’ social demographic characteristics. Agarwal and Yochum (1999) and Leones et al. (1998) found that age did not affect tourist expenditure. On the contrary, older travellers from Japan to the United States were found to spend more than their younger counterparts (Jang et al., 2004), whilst Wang et al. (2006) suggested a negative relationship between total expenditure and the age of travellers. In contrast, Mak et al. (1977) found middle-aged American travellers had a higher expenditure in Hawaii on a daily basis, but stayed significantly shorter than young and aged travellers. In addition, age may not act independently but may work with other socio-demographic characteristics (e.g. the number and age of the male or female adults in the travel party) to influence the level of expenditure (Downward \& Lumsdon, 2000). Gender was not associated with the level of spending (Agarwal \& Yochum, 2000; Jang et al., 2004). Those who are not married were found to spend more than those that are in Mak et al. (1977), but the opposite was found by Asgary et al. (1997). However, two more recent studies conducted by Cannon and Ford (2002) and Wang et al. (2006) suggested that marital status did not influence the level of spending.

Trip characteristics, such as travel party size, length of stay, and first-time/repeat visitors have also been frequently used to explain expenditure. An increase in travel party size resulted in an increase in total travel expenditure (Agarwal \& Yochum, 1999), but a decrease in total expenditure per person per day (Taylor et al., 1993). As children are not income 
earners, number of children in the travel party was negatively related to total party expenditure (Agarwal \& Yochum, 1999). However, Wang et al. (2006) found that number of children did not affect total expenditure. Instead, number of adults in the travel party positively influenced total expenditure. In contrast, Jang et al. (2004) argued that it was not number of adults, but whether the traveller had companions or not affected total spending.

Length of stay at the destination can also significantly influence travellers' expenditure (Agarwal \& Yochum, 1999; Downward \& Lumsdon, 2004; Taylor et al., 1993; Wang et al., 2006). Its impact was positive on total tourist expenditure (Agarwal \& Yochum, 1999; Downward \& Lumsdon, 2004), but negative on daily personal tourist expenditure (Taylor et al., 1993). Wang et al. (2006) and Mak et al. (1977) found that expenditure did not differ between first-time and repeat visitors whilst Jang et al. (2004) suggested that repeat visitors tend to spend less on shopping than first-time visitors. Package tourists were found to have an expenditure 10 percent lower than the average of all tourists to Australia (Laesser \& Crouch, 2006).

The above review indicates that income, socio-demographic and trip-related characteristics are by far the most commonly used variables in explaining individuals’ demand for tourism products. In general, very few studies have attempted to investigate the impact of psychological and supply-related factors on travellers' expenditure, although theoretically, these variables may also affect how much people spend. Multiple regression analysis has been the most commonly used modelling technique. However, the models were often not able to sufficiently explain the level of expenditure, with an explanatory power below 20 percent. This strongly suggests a need to search for new variables that can improve the 
predictability of the expenditure function. The following section discusses the possible impact of satisfaction on expenditure, one of the focuses of the present study.

\section{Expenditure and satisfaction}

Satisfaction has been a long-standing focal point for tourism marketing due to its impact on travellers' post-trip behaviour and future decisions on travel; in other words, an individual's future demand for travelling to a destination (i.e., Heung, Wong, \& Qu, 2002; Kau \& Lim, 2005; Lee, Graefe \& Burns, 2004). However, would satisfaction also influence the current demand, such as an individual's level of expenditure during a trip? Theoretically, the satisfaction one derives from consumption impacts upon how one spends money. Business literature has demonstrated that customer satisfaction has been an important focus of business strategies due to its positive link to financial performance and economic return for the businesses (e.g. Anderson, Fornell \& Rust, 1997; Anderson, Fornell \& Lehmann, 1994; Reichheld \& Sasser Jr, 1990). This is because satisfied customers are willing to pay higher prices, which subsequently increases the revenue and profit.

Customers are willing "to pay more for a product or service which precisely matches their needs” (Hill \& Alexander, 2006, p. 220). Equity theory suggests that consumers seek to maintain equity between their inputs and outputs in an exchange process. Based on this theory, a highly satisfied customer expects high outcome from an exchange and is willing to pay more to re-establish equity whilst a highly dissatisfied customer would want to pay less (Homburg, Koschate, \& Hoyer, 2005). The disappointment theory also indicates that the satisfaction/dissatisfaction is a result of positive/negative disconfirmation between expectation and perception and this process generates additional values (positive or negative) to the consumption or usage experience (Homburg et al., 2005). Nevertheless, it is not certain with respect to whether intention/willingness does generate purchase behaviour. It is 
therefore important to directly test the relationship between satisfaction and actual purchase behaviour/expenditure occurred.

Emotion may arouse or be aroused by satisfaction. Expectancy/anticipation, as an emotional factor, forms the basis for expectancy confirmation/disconfirmation, thus affects satisfaction in a consumptive situation (Holbrook, 1986). Satisfaction response may be in the emotional modes of contentment, pleasure, delight, relief and ambivalence (Arnould, Price, \& Zinkhan, 2004), and more pleasure experienced during consumption leads to higher satisfaction (Wirtz \& Bateson, 1999). A number of studies in retailing literature have explored the effect of emotion and satisfaction on expenditure, which generated mix results. Evidence showed that emotion had significant and direct influence of shoppers' expenditure of time and money at the shopping mall and a good mood is associated with higher expenditure at the mall (Babin \& Darden, 1995 \& 1996). Shim and Eastlick (1998) also found that shoppers who held favourable attitudes toward the mall's attributes are more likely to spend at the mall. However, Stoel, Wickliffe, and Lee (2004) argued that, although higher satisfaction led to an increase in time spent at the mall, it did not necessarily increase the level of expenditure at the mall. Additionally, the overall satisfaction with the shopping trip positively correlated with shoppers' perceptions of hedonic and utilitarian value resulting from their trip, which is also positively correlated with level of shopping expenditure (Babin, Darden, \& Griffin, 1994).

The behaviour of international travellers takes place in a much broader context than a shopping trip to a regional mall. For this reason, in the context of international tourism, the impact of a wider range of factors may need to be taken into account when modelling expenditure. However, the above-mentioned studies imply emotional factors and satisfaction 
as potential determinants of tourist expenditure in a destination, especially considering two reasons. According to Fornell and Rust (2005), service quality is less standardized and consistent than the quality of tangible goods. Consequently, changes in customer satisfaction will have a greater impact on customers' spending on services than on tangible goods. Based on a meta-analysis of existing literature on customer satisfaction, Szymanski and Henard (2001) expressed a similar view by emphasising the importance of distinguishing intangible services from tangible as satisfaction plays a stronger role in decisions to buy intangible services. International travel to a destination involves many repeat purchases and ongoing service commitments. Cumulative satisfaction based on repeated experience has a stronger impact on consumption than transaction-specific satisfaction based on a single experience (Homburg et al., 2005). An example would be Chinese travellers' to Australia purchasing souvenirs and duty free goods in every city on their itinerary. It is reasonable to assume that the level of satisfaction with the first consumption experience in Australia has a strong impact on travellers' spending behaviour during the rest of the trip. Such effect would be strengthened toward the end of their stay in Australia.

\section{RESEARCH METHOD}

\section{Questionnaire design}

Based upon the literature review, it is proposed that Chinese holiday travellers' expenditure in Australia is affected by their income, socio-demographics, trip characteristics and satisfaction with the trip. It was assumed that travellers face the same price in Australia; therefore, price impact was not measured in this study. Although the 'International Visitor Survey’ conducted annually by Tourism Australia may capture the most representative sample for inbound tourism to Australia, the survey was not specifically tailored to suit different inbound markets and research purposes (e.g., lack of data on income). Therefore, a 
self-designed questionnaire was used to collect data on Chinese holiday travellers, which include:

- total and disaggregated expenditures on various categories of tourism products;

- income and social demographic characteristics including gender, age, place of residence, marital status, level of education, occupation, annual income, and dependent children;

- trip characteristics such as first/repeat visitor, number of nights spend in Australia, stop over in other destinations on the way to Australia or on the return; and

- $\quad$ satisfaction with the overall trip and various components of the trip including accommodation, food and drink, tourist attractions, shopping, air transportation, tour itinerary, transfer between sites, tour guide, and other leisure activities (measured on a 5-point Likert Scale with 1 being 'strongly dissatisfied' through to 5 being 'strongly satisfied').

The questionnaire consists of mostly factual questions where the range of answers to a question is limited and pre-coded questions are generally preferred (Moser \& Kalton, 2004). Decisions on the pre-coded answers consulted previous studies focusing on the Chinese outbound travel market as well as the official statistics released by both the Australian and Chinese governments. For instance, place of residence has ten pre-coded categories that include the nine regions covered by the Approved Destination Status (ADS) operation at the time the study was conceptualised, plus a category for other areas. Age was measured in unit of 5 years from 15-19 to 70 and over. For each category to receive enough respondents, the pre-coded answers were collapsed into fewer categories in data analysis.

\section{The sample and survey administration}

Although the theoretical population of the survey includes all Chinese holiday tourists to Australia, it was impossible to draw a large national sample across different Australian states, 
given the limited research resources. Additionally, accurate tourist expenditure data can only be collected at the end of visitors' trips after the consumption has finished. The study thus decided to focus on the accessible population of Chinese holiday tourists departing from Brisbane. The survey was conducted in the Brisbane International Airport during a three week period. Departing Chinese travellers were approached randomly for their voluntary participation in the study. In total, 380 usable questionnaires were collected.

\section{Data analysis techniques}

The bivariate analysis of correlation, independent sample t-test and ANOVA were used to examine the individual effect of various social-demographic characteristics, trip characteristics, and satisfaction on travellers' expenditure in the preliminary analysis stage. Then, the multiple regression analysis was performed to confirm the results of bivariate analyses, and to show the collective effect of independent variables on expenditure.

\section{FINDINGS}

\section{Trip expenditures}

Table 1 reports Chinese travellers' total and disaggregated expenditures. Expenditures were measured in Australian dollars. The results revealed that the average total expenditure per person per trip by Chinese tourists is $\$ 4,658$ and the cost of tour package averaged $\$ 3,154$. With regard to Chinese tourists' expenditure in Australia, the average is $\$ 1,426$. The coefficient of variation (CV), a proportionate measure of variability that allows for comparison of relative variability of more than one data set, indicated that total expenditure in Australia has the largest relative variability whilst tour package has the smallest variability. On average, Chinese tourists spent \$166 or 22 percent of their total expenditure in Australia on food and drink during their stay in Australia. They also spent \$887 on shopping to take home, \$349 on gambling/entertainment, and \$179 on cultural/sporting activities. The large values for standard deviation indicate a high variability in travellers’ expenditure. 
Insert Table 1 here

\section{Expenditures by traveller characteristics}

Table 2 to Table 4 report the characteristics of the sample and the expenditures by those characteristics. Five expenditure categories are reported: total expenditure per person in Australia, and expenditure per person on shopping, cultural/sporting activities, food/drinks, and gambling/entertainment. Preliminary analysis using bivariate techniques found significant differences in the expenditures of travellers of different socio-demographic and trip characteristics. These significant differences are marked in the tables with asterisks. In the preliminary analysis, the expenditure data were log transformed to satisfy the normality assumption of the analytical tests performed.

Insert Table 2 here

There are slightly more males (56.6\%) than females (43.4\%) in the sample. About $64.9 \%$ of the participants are aged between 30 and 49 . Three-quarters of the visitors are married, and among 277 married travellers, about three-quarters have dependent children. Chinese tourists aged between 30 and 49 had a significantly higher total expenditure than those aged below 30. The expenditure difference between the two groups is $\$ 456$. The expenditure on gambling/entertainment of those who have a dependent child is \$241 higher than those who do not have. Chinese tourists’ expenditures on shopping, cultural/sporting activities and food/drink were not affected by the dependent child factor, neither was their total expenditure in Australia. The results suggest no difference in visitors' total and disaggregated expenditures between single and married visitors.

Table 3 reports Chinese travellers’ expenditure by place of residence, education level, occupation and income. Nearly $80 \%$ of the travellers have tertiary education or above. An 
ANOVA test suggested that both people with senior middle school qualification (\$191) and people with undergraduate degree (\$300) spent less on gambling/entertainment than people having junior middle school qualification or below $(\$ 940)$.

\section{Insert Table 3 Here}

Four main places of origin in this sample are Beijing, Shanghai, Guangdong and Zhejiang, which together contributed more than two-thirds of the respondents. The total expenditure of visitors from Zhejiang province is $\$ 979$ higher than that of Guangdong residents. With regard to occupation, business owners, managers and professionals ranked as the top three and jointly accounted for $63.8 \%$ of the total respondents. Government official, clerk, plant and machine operator and assembler, retired/unemployed categories were classified with all other occupations to form the “Other” category. Altogether, these professions represent $20.4 \%$ of the sample. As shown in the table, Chinese managers (\$1424) spent significantly more on shopping than professionals (\$699). Professionals (\$94) spent less on food and drink than other occupations $(\$ 276)$.

About $21 \%$ of the visitors have an income above $¥ 300,000$ and visitors with income below $¥ 100,000$ account for $48.6 \%$ of all the survey participants. As indicated in the table, total expenditure and expenditure on cultural/sporting activities differed across different income groups. The income group of above $¥ 300,000$ spent $\$ 1055$ more per head in total than the below $¥ 100,000$ income group. Regarding expenditure on cultural/sporting activities, the below $¥ 100,000$ income group (\$112) spent significantly less than the other two income groups (\$209). 


\section{Expenditures by trip characteristics}

As shown in Table 4, first-time travellers dominated the sample (92.2\%). Travellers who visited Australia for the first time (\$354) spent significantly less on gambling/entertainment than repeat visitors (\$899). However, this result needs to be interpreted with caution due to the small sample size (7) of repeat visitors.

Insert Table 4 here

The numbers of nights in Australia were grouped into three categories: 6 nights and under, 7 to 8 nights and 9 nights and over. Differences existed in the total expenditure, expenditure on shopping, gambling/entertainment and food/drink across travellers of different lengths of stay. The highest expenditure occurred in the category of seven to eight nights. Travel party size also had a significant impact on visitors' total expenditure and expenditure on shopping and gambling/entertainment. For instance, in terms of total expenditure, those who travelled individually (\$2126) spent significantly more than those who travelled in groups of three (\$1351) and four or more (\$840). On their trip to Australia, two-thirds of the Chinese tourists visited countries/destinations other than Australia. There is a significant difference in the total spending between travellers who visited Australia only (\$1343) and those who visited multiple destinations (\$1802).

\section{Expenditure and satisfaction}

Overall satisfaction was measured by a compound variable: the average score of the overall trip and trip elements. Using a compound variable "reduces the measurement error by using multiple indicators to reduce the reliance on a single response", and has the "ability to represent the multiple aspects of a concept in a single measure” (Hair, Anderson, Tatham, \& Black (1998, p. 116, 117). The correlation analysis performed between total expenditure and overall satisfaction produced a significant but low coefficient of $-0.169(p<0.01)$. The 
negative coefficient seems to suggest a decreasing expenditure in association with an increasing level of satisfaction.

\section{Regression analysis results}

A regression analysis using ordinary least squares (OLS) estimation method was performed on total expenditure as the dependent variable and its determinants as the independent variables. The expenditure was log transformed to satisfy the normality assumption. This can also remove the outliers and deal with the heteroskedasticity problem (Downward \& Lumsdon, 2004). Two regression models were estimated. The first model includes all the social demographic, trip-related and satisfaction variables whereas the second model takes account of only those variables tested significant in the preliminary analysis (income, age, place of residence, travel party size, length of stay, single/multiple destinations, and satisfaction). The second model reported in Table 5 has a higher adjusted R square value and is free of multicollinarity. The independent variables in the regression model were measured in the natural units. Dummy variables were created for each categorical variable using indicator coding. In such coding, K-1 dummy variables are created to represent a categorical variable with K levels. The effect of the omitted level (also called the reference category) is captured by the constant term in the regression model. The regression coefficients for the dummy variables represent the difference on the dependent variable for each level of the variable from the reference category (Hair, Black, Babin, Anderson, \& Tatham, 2005). The reference group in this analysis consists of visitors aged below 30, residing in Zhejiang province, visited multi-destination, stayed in Australia for more than 8 nights, and having an annual income of more than ¥300,000.

Insert Table 5 here 
There is an overall relationship between total expenditure per person in Australia and the independent variables, given that the overall model is significant, with $F(12,203)=6.645, p$ $<0.001$. The model has an adjusted R square of 0.254 suggesting that all the independent variables together explained 25.4 percent of the variation in visitors' expenditure. This is a satisfactory level of explanatory power given that the study used the cross-sectional data, which, according to Asgary, De Los Santos, Vincent, and Davila (1997) would yield much lower R square compared to time series data.

Apart from the constant, four independent variables are significant at the 5 percent level and four other variables are significant at the 10 percent level, indicating they had considerable impact on the total expenditure per person in Australia. These variables are travel party size and dummy variables for age 30 to 49, place of residence in Beijing, visiting another destination, 6 nights and under, 7 to 8 night, income below $¥ 100,000$, and income between $¥ 100,000$ and $¥ 300,000$. The independent variable of overall satisfaction is not significant. Among the independent variables, travel party size contributes the most to the variation in the expenditure, given the largest magnitude in terms of the standardized coefficient.

The regression analysis involves using log-transformed dependent variable (also called semilog regression equation), in which the coefficient for a continuous variable is interpreted as the percentage change in dependent variable for a unit change in the independent continuous variable. Taking travel party size as an example, the regression coefficient is -..333, thus the total expenditure per person in Australia is expected to decrease by 33.3 percent given an additional person in the travel party. For dummy variables in the semi-log functional form, the percentage impact of a dummy variable on the dependent variable is calculated using the formula below 


$$
g=100(\exp (b-V(b) / 2)-1)
$$

Where $g$ is the percentage impact of the dummy variable on the dependent variable; $b$ is the regression coefficient for the dummy variable; $\mathrm{V}(\mathrm{b})$ is the estimated variance of the regression coefficient for the dummy variable (Halvorsen \& Palmquist, 1980).

Using formula (1), the percentage impacts of the significant dummy variables on the dependent variable of total expenditure per person in Australia were calculated and presented in the far right column of Table 5. For the dummy variable of age 30 to 49, the result can be interpreted as Chinese holiday tourists aged between 30 and 49 spent 38.8 percent more than those aged under 30 (the reference category) without taking into account the effects of other independent variables. This result is not surprising as travellers under 30 years old are less established career-wise, earn less money, and have less saving. This age cohort also includes student travellers who were funded by their parents and subsequently had a less flexible travel budget. Residents of Beijing spent 38.3 percent less than those of Zhejiang. A multiple destination tour package costs substantially more than a single destination package that may imply a higher affordability of multiple destination travellers as compared to travellers who visited Australia only. As a result, multiple-destination travellers spent 23.3 percent more in Australia than those who visited Australia only. With regard to the length of stay in Australia, the reference group of 8 nights and more had an average expenditure that is 29.6 percent higher than the short stay group (6 nights and under), but is 40.9 percent lower than people stayed who 7 or 8 nights. The reason behind this phenomenon may be associated with the travel itinerary and the standard of the package. The effect of the income is as expected. Travellers’ of high income spent 38.8 and 31.6 percent more than the low and middle income travellers. Diagnostic check of multicollinearity using tolerance and variance inflation factors (VIF) are presented in Table 5, showing no concern of multicollinearity problem in the 
regression analysis. Other diagnostic check results show that the assumptions of linearity, normality and multivariate outliers are also satisfied.

\section{Further analysis on expenditure and satisfaction}

The results of further analysis using ANOVA on overall trip experience in relation to total expenditure in Australia are displayed in Table 6. Satisfaction levels that received fewer than five responses were excluded from the analysis. The ANOVA obtained a significant $F$ statistic $(F(2,219)=5.649, p<0.01)$. The multiple comparisons show that travellers who were strongly satisfied (\$890) were found to spend significantly less than those who stated “neutral” feeling with their overall trip experience (\$2086).

\section{Insert Table 6 here}

An ANOVA was performed on levels of satisfaction with shopping in relation to shopping expenditure. A significant $F$ value $(F(4,206)=4.257, p=0.025)$ was obtained and the figures suggest that tourists having high spending on shopping were either satisfied or strongly dissatisfied (see Table 7). The multiple comparisons show that those tourists who were satisfied with shopping (\$1416) spent significantly more on shopping than neutrally satisfied (\$815) and dissatisfied tourists (\$619).

Insert Table 7 here

\section{DISCUSSION AND IMPLICATIONS}

At the individual level, direct tourist expenditure is the most commonly used indicator of a tourist's contribution to the destination's economy and the expenditure can vary very widely from one traveller to another. This study revealed an average of \$217 per night spending in Australia by Chinese travellers for holiday purposes as compared to $\$ 82$ by all Chinese travellers, $\$ 90$ by all international travellers in 2005 (Bureau of Tourism Research, 20002005), and an average daily expenditure of $\$ 104$ by Chinese business travellers in Australia (Tourism Australia, 2006a; 2006b). This suggests that on a daily basis, Chinese holiday 
travellers make a higher economic contribution than other market segments and therefore should attract more marketing efforts.

The literature shows that expenditure-based segmentation is viable and practical (Spotts \& Mahoney, 1991; Pizam \& Reichel, 1979). People who have high expenditure can be distinguished from those who have low expenditure in terms of economic and social demographic characteristics (Mudambi \& Baum, 1997) and trip-related characteristics (Spotts \& Mahoney, 1991). Identifying high-yield market segment is particularly important for destinations when operating in a mass tourism market like China. The Chinese holiday travel market is dominant by pre-paid package travel, which is commonly associated with high expenditure leakage due to the fact that packages were purchased before the trip and a significant proportion of the expenditure on package stays in the origin country. A feasible strategy to maximize the economic benefit from the Chinese holiday market is to attract those tourists who have high expenditure during their stay in the destination.

This study examined the spending pattern of Chinese holiday travellers to Australia and investigated the factors determining their expenses occurred in Australia. There was a huge variation in Chinese holiday tourists' expenditure, suggesting the market may be segmented according to the volume of spending. The study revealed that Chinese travellers' total and disaggregated expenditures in Australia varied across people of different socio-demographic background and trip characteristics, as summarized in Table 8.

Insert Table 8 here

Chinese visitors' total expenditure in Australia varied according to their income, age, place of residence, travel party size, length of stay, and visitation to other destination(s), among which 
travel party size and length of stay seemed to influence the level of expenditure to a greater extent than other variables. With respect to the difference in expenditures on shopping, occupation, travel party size and length of stay were the contributing factors. Expenditure on cultural and sporting activities was only affected by visitors' income and visitation to other destination(s). Two variables, occupation and length of stay influenced Chinese visitors’ expenditure on food and drinks. In addition, the factors of dependent child, education level, travel party size, length of stay, and first/repeat visit significantly affected visitors’ expenditure on gambling and entertainment. In contrast, gender and marital status had the least impact on visitors’ level of spending.

The identification of the relationships between Chinese travellers' expenditure and their socio-demographics and trip-related characteristics provides information to Australia's destination marketers in regard to variables that can help identify the high yield segments in this market. A heavy spender in terms of total expenditure is a sole traveller earning more than $¥ 300,000$ a year, aged between 30 to 49 years, residing in Zhejiang province, staying in Australia for 7 to 8 days, and visiting a secondary destination in addition to Australia. This is the segment that Australia, as a destination, should pursue. The high yield shopping segment consists of travellers who hold a managerial position, travel alone and stay for 7 to 8 nights. Travellers having high expenditure on cultural and sporting activities usually visit multiple destinations and earn more than $¥ 300,000$ per annum. A big spender on food and drink has a length of stay of 7 to 8 nights and is not a business owner, manager, professional, or student. The gambling and entertainment sector should focus on tourists who are repeat visitors, travelling alone, having dependent child, not well-educated, and staying for 7 to 8 night. 
To cater for different segments, differentiated products are needed. However, this study revealed that tour packages are homogenous in terms of price. It may be assumed that the packages are highly standardised and little effort has been put into market segmentation. With limited options, Chinese travellers with different purchasing power and expectations were forced into similar packages. This may have resulted in the huge variation in expenditures on products not included in the packages, such as shopping. Appropriate research needs to be conducted with respect to high yield Chinese visitors’ preferences for tourist activities, destinations, travel modes, etc. Effective packaging can then be achieved based on research undertaken.

There has been anecdotal evidence in the areas other than tourism and hospitality that emotional factors and satisfaction may influence people’s expenditure (Babin \& Barden, 1995; Babin et al. 1994; Shim \& Eastlick, 1998). Satisfaction is said to influence travellers’ decision to re-visit the destination and preference to recommend the destination to others. In this sense, satisfaction can affect travellers’ future consumption/expenditure. However, there is no empirical evidence of whether satisfaction can also affect travellers' consumption decisions during their trip. One of the differentiating characteristics of this study is to investigate how satisfaction is related to tourist expenditure. The study found that expenditure varied across different satisfaction levels, but the relationship between the two variables is not linear as indicated by the insignificant regression analysis results. Varied level of spending on shopping was also observed across different levels of satisfaction with shopping. High spending travellers were either satisfied or strongly dissatisfied. Shopping was a very important element in Chinese travellers' tour itinerary and Chinese travellers engaged in multiple shopping activities during the trip. Satisfaction with the first one or two shopping activities may increase the likelihood of participating in more shopping activities. If such an 
assumption is upheld, satisfaction can bring about higher expense on shopping. However, for a small group of travellers, their high expenditure may, in fact, be the cause of dissatisfaction. For instance, if a traveller purchased a considerable amount of duty free goods under the influence of others (e.g., a tour guide) or if the purchase was an impulse decision, and later he/she found out that the goods were over-priced, of poor quality, or not what he/she really wanted, the feeling of being tricked into buying could lead to a high level of dissatisfaction. This may explain the high expenditure by strongly dissatisfied travellers. It also validated Weber's claim (1997) that expenditure can affect travellers' evaluation of the trip, especially when travel is expensive to travellers.

\section{CONCLUSION}

In terms of the total economic value, China is currently Australia's fourth largest inbound tourism market (Tourism Australia, 2008) with the potential to become its largest market in 2016 (Tourism Forecasting Committee, 2007). It is unlikely that such a huge market is homogenous and sensibly segmenting the Chinese holiday market is essential for Australia to operate successfully in this market. This study investigated Chinese holiday travellers' expenditure in Australia. It provided a review of tourist expenditure analyses, which identified three major groups of variables that have been commonly included in the expenditure studies: economic, socio-demographic, and trip-related variables. The empirical results regarding the effect of these variables on expenditure are often in conflict, suggesting a need for further investigation into this area. This study examined the individual and joint effects of a selective number of economic, socio-demographic and trip-related characteristics on level of expenditure. The results provided additional evidence into the role of these characteristics in determining how much travellers spend. It is also the first such study conducted for Chinese outbound travel market. 
Tourist destinations are more interested in attracting high-yield tourists who have high per capita spending than simply increase the number of tourists. This study concludes that whilst a large proportion of Chinese travellers may be conscious of travel cost, there are segments within this market that are relatively more affluent and less price sensitive. Chinese travellers' total and disaggregated expenditures were found to be associated with different sets of social demographics, trip characteristics and psychological factors. In terms of total expenditure, Chinese holiday travellers can be segmented and targeted based on their income, age, place of residence, travel party size, length of stay, and visitation to other destinations. The findings of this study may help Australia gain maximum benefit from the holiday travel demand from China.

Although psychological variables have been recognized as important influencers of people’ travel-related decisions (Laesser \& Crouch, 2006; Murphy, 1985; Wang et al. 2006), only a limited number of tourism studies have incorporated such variables and no study in the field of tourism and hospitality has considered the effect of visitor satisfaction on travel expenditure. Therefore, another theoretical contribution of this study is related to its effort to explore the effect of satisfaction on travellers' spending behaviour. As revealed in this study, the level of total and shopping expenditures seemed to be associated with the level of satisfaction. The study offered the first step in examining how visitor satisfaction may affect tourist expenditure. Future studies can expand on these results to examine the relationship between expenditure and satisfaction using national samples or in other markets. Additionally, due to practical reasons, this study only examined a limited number of variables. The effect of other variables, especially psychological factors, on tourist expenditure is a research topic of interest for future studies. 


\section{REFERENCES}

Agarwal, V. B., and Yochum, G. R. (1999). Tourist spending and race of visitors. Journal of Travel Research, 38(2), 173-176.

Agarwal, V. B., and Yochum, G. R. (2000). Determinants of tourist spending. In A. G. Woodside, G. I. Crouch, J.A. Mazanec, M. Oppermann \& M. Y. Sakai (Eds.), Consumer Psychology of Tourism, Hospitality and Leisure (Vol. 1, pp. 311-330). Wallingford, UK: CABI Publishing.

Aguilo Perez, E., and Juaneda Sampol, C. (2000). Tourist expenditure for mass tourism markets. Annals of Tourism Research, 27(3), 624-637.

Alegre, J., and Pou, L. (2004). Micro-economic determinants of the probability of tourism consumption. Tourism Economics, 10(2), 125-144.

Anderson, E. W., Fornell, C., and Lehmann, D. R. (1994). Customer satisfaction, market share, and profitability: Findings from Sweden. Journal of Marketing, 58(3), 53-66.

Anderson, E. W., Fornell, C., and Rust, R. T. (1997). Customer satisfaction, productivity, and profitability: Differences between goods and services. Marketing Science, 16(2), 129145.

Arnould, E., Price, L., and Zinkhan, G. (2004). Consumers (2nd Ed.). Boston: McGraw Hill/Irwin.

Asgary, N., De Los Santos, G., Vincent, V., and Davila, V. (1997). The determinants of expenditures by Mexican visitors to the border cities of Texas. Tourism Economics, 3(4), 319-328.

Babin, B. J., Darden, W. R., and Griffin, M. (1994). Work and/or fun: Measuring hedonic and utilitarian shopping value. The Journal of Consumer Research, 20(4), 644-656.

Babin, B. J., and Darden, W. R. (1995). Consumer self-regulation in a retail environment. Journal of Retailing, 71(1), 47-70. 
Babin, B. J., and Darden, W. R. (1996). Good and bad shopping vibes: Spending and patronage satisfaction. Journal of Business Research, 35(3), 201-206.

Bureau of Tourism Research. (2000-2005). International visitor survey. Canberra: BTR.

Cai, L. A., and Knutson, B. J. (1998). Analysing domestic tourism demand in China: A behavioural model. Journal of Hospitality and Leisure Marketing, 5(2/3), 95-113.

Cai, L. A., Hu, B., and Feng, R. (2001). Domestic tourism demand in China's urban centres: Empirical analyses and marketing implications. Journal of Vacation Marketing, 8(1), 64-74.

Cannon, T. F., and Ford, J. (2002). Relationship of demographic and trip characteristics to visitor spending: An analysis of sports travel visitors across time. Tourism Economics, 8(3), 263-271.

Chen, Y., Guo, Y., Wang, K-C., and Wang, Y. (2005). An empirical study on economic impacts of mainland Chinese outbound tourism by pleasure travellers. Paper presented at the Fourth Annual Asia Pacific Forum for Graduate Student Research in Tourism, August 1-3, Hawaii.

Chon, K. (2005). Opening Address for the Second China Tourism Forum and the Third China Tourism Academy Annual Conference, December 16-17, Kunming, China.

Crouch, G. I. (1994). The study of international tourism demand: A survey of practice. Journal of Travel Research, 33(4), 41-55.

Deaton, A., \& Muellbauer, J. (1980). Economics and Consumer Behaviour. Cambridge: Cambridge University Press.

Downward, P., and Lumsdon, L. (2000). The demand for day-visits: An analysis of visitor spending. Tourism Economics, 6(3), 251-261.

Downward, P., and Lumsdon, L. (2003). Beyond the demand for day-visits: An analysis of visitor spending. Tourism Economics, 9(1), 67-76. 
Downward, P., and Lumsdon, L. (2004). Tourism transport and visitor spending: A study in the North York Moors National Park, UK. Journal of Travel Research, 42(4), 415420.

Fornell, C., and Rust, R. T. (2005, September 9). The Effect of Buyer Satisfaction on Consumer Spending Growth. Retrieved June 20, 2007, from http://www.ivey.uwo.ca/Research/IRS_Papers/Rust.pdf

Frechtling, D. C. (2006). An assessment of visitor expenditure methods and models. Journal of Travel Research, 45(1), 26-35.

Halvorsen, R., and Palmquist, R. (1980). The interpretation of dummy variables in semilogarithmic equations. American Economic Review, 70(3), 474-475.

Hair, J. F., Anderson, R. E., Tatham, R. L., \& Black, W. C. (1998). Multivariate Data Analysis (5th ed.). Upper Saddle River, N.J.: Prentice Hall.

Hair, J. F., Black, W. C., Babin, B. J., Anderson, R. E., and Tatham, R. L. (2005). Multivariate Data Analysis, (6th ed.). Upper Saddle River, NJ: Pearson Education.

Heung, V. C. S., Wong, M. Y., and Qu, H. (2002). A study of tourists' satisfaction and postexperience behavioural intentions in relation to airport restaurant services in the Hong Kong SAR. Journal of Travel and Tourism Marketing, 12(2/3), 111-135.

Hill, N., and Alexander, J. (2006). Handbook of Customer Satisfaction and Loyalty Measurement. Aldershot, Hampshire, England: Gower Publishing, Ltd.

Holbrook, M. B. (1986). Emotion in the consumption experience: Toward a new model of the human consumer. In R. A. Peterson, W. D. Hoyer, and W. R. Wilson (Eds.), The Role of Affect in Consumer Behaviour (pp. 17-52). Lexington, MA: Heath.

Homburg, C., Koschate, N., and Hoyer, W. D. (2005). Do satisfied customers really pay more? A study of the relationship between customer satisfaction and willingness to pay. Journal of Marketing, 69(2), 84-96. 
Jang, S. C., Bai, B., Hong, G-S., and O'Leary, J. T. (2004). Understanding travel expenditure patterns: A study of Japanese pleasure travelers to the United States by income level. Tourism Management, 25(3), 331-341.

Jang, S. C., Cai, L. A., Morrison, A. M., and O'Leary, J. T. (2005). The effect of travel activities and seasons on expenditure. International Journal of Tourism Research, 7(6), 335-346.

Kau, A-K., and Lim, P-S. (2005). Clustering of Chinese tourists to Singapore: An analysis of their motivations, values and satisfaction. International Journal of Tourism Research, 7(4/5), 231-248.

Kotler, P. (1988). Marketing Management: Analysis, Planning, Implementation, and Control. Englewood Cliffs, NJ: Prentice Hall.

Laesser, C., and Crouch, G. I. (2006). Segmenting markets by travel expenditure patterns:

The case of international visitors to Australia. Journal of Travel Research, 44(4), 397406.

Lee, J., Graefe, A. R., and Burns, R. C. (2004). Service quality, satisfaction, and behavioral intention among forest visitors. Journal of Travel \& Tourism Marketing, 17(1), 73-82.

Legohérel, P. (1998). Toward a market segmentation of the tourism trade: Expenditure levels and consumer behavior Instability. Journal of Travel and Tourism Marketing, 7(3), 19-39.

Leones, J., Colby. B., and Crandall, K. (1998). Tracking expenditures of the elusive nature tourists of Southeastern Arizona. Journal of Travel Research, 36(3), 56-64.

Lim, C. (2006). A survey of tourism demand modelling practice: Issues and implications (4572). In L. Dwyer, \& P. Forsyth (Eds.), International Handbook on the Economics of Tourism. Cheltenham, UK: Edward Elgar Publishing.

Mak, J., Moncur, J., and Yonamine, D. (1977). Determinants of visitor expenditures and 
visitor lengths of stay: A cross-section analysis of US visitors to Hawaii. Journal of Travel Research, 15(3), 5-8.

Mok, C., and Iverson, T. J. (2000). Expenditure-based segmentation: Taiwanese tourists to Guam. Tourism Management, 21(3), 299-305.

Moufakkir, O., Singh, A. J., Moufakkir-van der Woud, A., and Holecek, D. F. (2004). Impact of light, medium and heavy spenders on casino destinations: Segmenting gaming visitors based on amount of non-gaming expenditures. UNLV Gaming Research and Review Journal, 8(1), 59-71.

Mudambi, R., and Baum, T. (1997). Strategic segmentation: An empirical analysis of tourist expenditure in Turkey. Journal of Travel Research, 36(1), 29-34.

Murphy, P. E. (1985). Tourism: A Community Approach. New York: Methuen.

Pizam, A., and Reichel, A. (1979). Big spenders and little spenders in US tourism. Journal of Travel Research, 18(1), 42-43.

Qu, H., and Lam, S. (1997). A travel demand model for Mainland Chinese to Hong Kong. Tourism Management, 18(8), 593-597.

Reichheld, F. F., and Sasser Jr., W. E. (1990). Zero defections: Quality comes to services. Harvard Business Review, 68(5), 105-111.

Ryan, C. (2003). Recreational Tourism: Demand and Impacts. Clevedon: Channel View Publications.

Seiler, V. L., Hsieh, S., Seiler, M. J., and Hsieh, C. (2002). Modeling travel expenditures for Taiwanese tourism. Journal of Travel and Tourism Marketing, 3(4), 47-61.

Shim, S., and Eastlick, M. A. (1998). The hierarchical influence of personal values on mall shopping attitude and behaviour. Journal of Retailing, 74(1), 139-160.

Sinclair, T. M., and Stabler. M. (1997). The Economics of Tourism. London: Routledge. Song, H., and Witt, S. F. (2000). Tourism Demand Modelling and Forecasting: Modern 
Econometric Approaches. New York: Pergamon.

Spotts, D. M., and Mahoney, E. M. (1991). Segmenting visitors to a destination region based on the volume of their expenditures. Journal of Travel Research, 29(4), 24-31.

Stoel, L., Wickliffe, V., and Lee, K-H. (2004). Attribute beliefs and spending as antecedents to shopping value. Journal of Business Research, 57(10), 1067-1073.

Szymanski, D. M., and Henard, D. H. (2001). Customer satisfaction: A meta-analysis of the empirical evidence. Journal of the Academy of Marketing Science, 29(1), 16-35.

Taylor, D. T., Fletcher, R. R., and Clabaugh, T. (1993). A comparison of characteristics, regional expenditures, and economic impact of visitors to historical sites with other recreational visitors. Journal of Travel Research, 32(1), 30-35.

Tourism Australia. (2006a, June 14). China: Visitor Profile. Retrieved September 10, 2006, from http://www.tourism.australia.com/content/China

Tourism Australia. (2006b, October). China: Outbound Business Travel Snapshot. Retrieved June 10, 2007, from http://www.tourism.australia.com/content/Events/Outbound\%20BT\%20Snapshot/Chi na_Travel_Snapshot.Sept2006.pdf

Tourism Australia. (2008). China: Visitor Profile 2007. Retrieved July 25, 2008, from http://www.tra.australia.com/content/documents/Visitor\%20Profile/2008/China.pdf. Tourism Forecasting Committee. (2007). Forecast 2007 Issue 2. Canberra: Tourism Research Australia.

Wang, Y., Rompf, P., Severt, D., and Peerapatdit, N. (2006). Examining and identifying the determinants of travel expenditure pattearns. International Journal of Tourism Research, 8(5), 333-346. 
Weber, K. (1997). Assessment of tourist satisfaction, using the expectancy disconfirmation theory: A study of German travel market in Australia. Pacific Tourism Review, 1(1), $35-45$.

Wirtz, J., and Bateson, J. E. G. (1999). Consumer satisfaction with services: Integrating the environment perspective in services marketing into the traditional disconfirmation paradigm. Journal of Business Research, 44(1), 55-66. 


\section{Table 1}

Total and Disaggregated Expenditures per Person by Chinese Travellers

\begin{tabular}{|c|c|c|c|c|}
\hline Total expenditure & $\mathrm{N}$ & $\begin{array}{l}\text { 5\% } \\
\text { trimmed } \\
\text { mean }\end{array}$ & $\begin{array}{c}\text { Std. } \\
\text { deviation }\end{array}$ & $\begin{array}{l}\text { Coefficient } \\
\text { of variation }\end{array}$ \\
\hline Total expenditure on the trip & 280 & $\$ 4,658$ & $\$ 3,942$ & 0.85 \\
\hline Expenditure on tour package & 282 & $\$ 3,154$ & $\$ 495$ & 0.16 \\
\hline $\begin{array}{l}\text { Total expenditure in Australia } \\
\text { (excluding pre-paid package) }\end{array}$ & 291 & $\$ 1,425$ & $\$ 2,883$ & 2.02 \\
\hline $\begin{array}{l}\text { Per night expenditure in Australia } \\
\text { (excluding pre-paid package) }\end{array}$ & 265 & $\$ 217$ & $\$ 421$ & 1.94 \\
\hline Disaggregated Expenditure & $\mathrm{N}$ & $\begin{array}{c}5 \% \\
\text { Trimmed } \\
\text { Mean }\end{array}$ & $\begin{array}{c}\text { Std. } \\
\text { Deviation }\end{array}$ & $\begin{array}{l}\% \text { of Total } \\
\text { expenditure }\end{array}$ \\
\hline Food and drink & 126 & $\$ 166$ & $\$ 810$ & $22 \%$ \\
\hline Shopping to take home & 220 & $\$ 887$ & $\$ 2,773$ & $68 \%$ \\
\hline Gambling/entertainment & 116 & $\$ 349$ & $\$ 3,157$ & $28 \%$ \\
\hline Cultural/sporting activities & 45 & $\$ 179$ & $\$ 238$ & $22 \%$ \\
\hline
\end{tabular}

Note: Expenditures are in Australian dollars. 


\section{Table 2}

Expenditures by Gender, Age, Marital Status, and Dependent Children

\begin{tabular}{|c|c|c|c|c|c|c|c|c|}
\hline \multicolumn{2}{|c|}{$\begin{array}{l}\text { Social demographic } \\
\text { and trip characteristics }\end{array}$} & $\mathrm{N}$ & $\%$ & \multicolumn{5}{|c|}{ Expenditure per person (\$) } \\
\hline & & & & Total & Shopping & $\begin{array}{c}\text { Cultural } \\
\text { I } \\
\text { sporting }\end{array}$ & $\begin{array}{l}\text { Food/ } \\
\text { drinks }\end{array}$ & $\begin{array}{c}\text { Gambling/ } \\
\text { entertainment }\end{array}$ \\
\hline \multirow[t]{2}{*}{ Gender } & Male & 207 & 56.6 & $\$ 1,807$ & $\$ 1,089$ & $\$ 191$ & $\$ 163$ & $\$ 421$ \\
\hline & Female & 159 & 43.4 & $\$ 1,419$ & $\$ 1,007$ & $\$ 161$ & $\$ 194$ & $\$ 308$ \\
\hline \multirow[t]{3}{*}{ Age } & $\leq 30$ & 91 & 24.8 & $* \$ 1,347$ & $\$ 977$ & $\$ 170$ & $\$ 163$ & $\$ 344$ \\
\hline & $31-49$ & 240 & 64.9 & $* \$ 1,803$ & $\$ 1,039$ & $\$ 179$ & $\$ 194$ & $\$ 421$ \\
\hline & $\geq 50$ & 38 & 10.3 & $\$ 1,360$ & $\$ 1,205$ & --- & $\$ 85$ & $\$ 185$ \\
\hline Marital & Single & 88 & 23.5 & $\$ 1,601$ & $\$ 1,193$ & $\$ 196$ & $\$ 178$ & $\$ 465$ \\
\hline status & Married & 277 & 74.1 & $\$ 1,655$ & $\$ 1,020$ & $\$ 164$ & $\$ 175$ & $\$ 378$ \\
\hline Dependent & Yes & 198 & 73.3 & $\$ 1,766$ & $\$ 1,047$ & $\$ 180$ & $\$ 174$ & $* \$ 500$ \\
\hline children & No & 72 & 26.7 & $\$ 1,535$ & $\$ 1,081$ & $\$ 170$ & $\$ 175$ & *\$259 \\
\hline
\end{tabular}

Note: Expenditures are in Australian dollars. The above 50 age cohort category for expenditure on culture/sporting activities received no response. ${ }^{*}$ denotes significance at $5 \%$ level. The test results with respect to small samples need to be treated with caution. 
Table 3

\section{Expenditures by Place of Residence, Education, Occupation, and Income}

\begin{tabular}{|c|c|c|c|c|c|c|c|c|}
\hline \multicolumn{2}{|c|}{$\begin{array}{l}\text { Social demographic and trip } \\
\text { characteristics }\end{array}$} & $\mathrm{N}$ & $\%$ & \multicolumn{5}{|c|}{ Expenditure (\$) } \\
\hline & & & & Total & Shopping & $\begin{array}{l}\text { Cultural/ } \\
\text { sporting }\end{array}$ & $\begin{array}{l}\text { Food/ } \\
\text { drink }\end{array}$ & $\begin{array}{c}\text { Gambling/ } \\
\text { entertainment }\end{array}$ \\
\hline Place of & Beijing & 55 & 14.8 & $\$ 1,299$ & $\$ 848$ & $\$ 159$ & $\$ 221$ & $\$ 313$ \\
\hline \multirow[t]{4}{*}{ residence } & Shanghai & 91 & 24.5 & $\$ 1,685$ & $\$ 1,091$ & $\$ 151$ & $\$ 178$ & $\$ 393$ \\
\hline & Guangdong & 70 & 18.8 & $* \$ 1,264$ & $\$ 882$ & $\$ 291$ & $\$ 153$ & $\$ 369$ \\
\hline & Zhejiang & 39 & 10.5 & $* \$ 2,243$ & $\$ 1,422$ & $\$ 122$ & $\$ 161$ & $\$ 351$ \\
\hline & Other & 117 & 31.4 & $\$ 1,807$ & $\$ 1,107$ & $\$ 183$ & $\$ 168$ & $\$ 444$ \\
\hline \multirow[t]{5}{*}{ Education } & $\leq$ Junior school & 26 & 6.8 & $\$ 1,677$ & $\$ 1070$ & $\$ 333$ & $\$ 238$ & *\$940 \\
\hline & Senior school & 60 & 15.8 & $\$ 1,589$ & $\$ 825$ & $\$ 125$ & $\$ 141$ & *\$191 \\
\hline & College cert/diploma & 73 & 19.5 & $\$ 1,708$ & $\$ 1,246$ & $\$ 150$ & $\$ 267$ & $\$ 426$ \\
\hline & Undergrad degree & 160 & 42.7 & $\$ 1,633$ & $\$ 1,032$ & $\$ 182$ & $\$ 138$ & *\$300 \\
\hline & $\geq$ Postgrad degree & 56 & 14.9 & $\$ 1,646$ & $\$ 1,030$ & $\$ 162$ & $\$ 168$ & $\$ 469$ \\
\hline \multirow[t]{5}{*}{ Occupation } & Business owner & 94 & 25.2 & $\$ 1,840$ & $\$ 999$ & $\$ 162$ & $\$ 136$ & $\$ 275$ \\
\hline & Manager & 95 & 25.5 & $\$ 1,971$ & *\$1,424 & $\$ 223$ & $\$ 206$ & $\$ 330$ \\
\hline & Professional & 49 & 13.1 & $\$ 1,420$ & $* \$ 699$ & $\$ 93$ & $* \$ 94$ & $\$ 434$ \\
\hline & Student & 55 & 14.8 & $\$ 1,495$ & $\$ 810$ & $\$ 196$ & $\$ 180$ & $\$ 526$ \\
\hline & Other & 80 & 21.4 & $\$ 1,243$ & $\$ 940$ & $\$ 175$ & $* \$ 276$ & $\$ 605$ \\
\hline $\begin{array}{l}\text { Annual } \\
\text { personal }\end{array}$ & $\begin{array}{l}\leq ¥ 100,000 \\
(\$ 16,529)\end{array}$ & 177 & 48.6 & $\star \$ 1,346$ & $\$ 948$ & $* \$ 112$ & $\$ 197$ & $\$ 342$ \\
\hline \multirow[t]{2}{*}{ income } & $\begin{array}{l}¥ 100,001-300,000 \\
(\$ 16,529-49,587)\end{array}$ & 111 & 30.5 & $\$ 1,648$ & $\$ 1,034$ & *\$209 & $\$ 138$ & $\$ 345$ \\
\hline & $\begin{array}{l}\geq ¥ 300,001 \\
(\$ 49,587)\end{array}$ & 76 & 20.9 & $\star \$ 2,401$ & $\$ 1,294$ & *\$215 & $\$ 178$ & $\$ 519$ \\
\hline
\end{tabular}

Note: Expenditures are in Australian dollars. * denotes significance at $5 \%$ level. The test results with respect to small samples need to be treated with caution. Annual incomes are presented in both RMB $(¥)$ and Australian dollar $(\$)$. At the time of the survey, the average exchange rate was $\$ 1$ to $¥ 6.05$. 
Table 4

Expenditures by Trip Characteristics

\begin{tabular}{|c|c|c|c|c|c|c|c|c|}
\hline \multicolumn{2}{|c|}{$\begin{array}{l}\text { Social demographic and } \\
\text { trip characteristics }\end{array}$} & \multirow[t]{2}{*}{ N } & \multirow[t]{2}{*}{$\%$} & \multicolumn{5}{|c|}{ Expenditure (\$) } \\
\hline \multirow{3}{*}{$\begin{array}{l}\text { First-time/ } \\
\text { repeat visit }\end{array}$} & & & & Total & Shopping & $\begin{array}{l}\text { Cultural/ } \\
\text { sporting }\end{array}$ & $\begin{array}{l}\text { Food/ } \\
\text { drink }\end{array}$ & $\begin{array}{c}\text { Gambling/ } \\
\text { entertainment }\end{array}$ \\
\hline & $\begin{array}{l}\text { First-time } \\
\text { visitor }\end{array}$ & 332 & 92.2 & $\$ 1,693$ & $\$ 1,088$ & $\$ 179$ & $\$ 181$ & *\$354 \\
\hline & $\begin{array}{l}\text { Repeat } \\
\text { visitor }\end{array}$ & 28 & 7.8 & $\$ 1,119$ & $\$ 578$ & -- & $\$ 126$ & $* \$ 899$ \\
\hline Number of & $\leq 6$ nights & 186 & 57.1 & $* \$ 1,296$ & $* \$ 763$ & $\$ 146$ & $* \$ 141$ & $* \$ 318$ \\
\hline nights in & 7 to 8 & 98 & 28.5 & $* \$ 2,387$ & $* \$ 1,412$ & $\$ 242$ & $* \$ 259$ & $* \$ 538$ \\
\hline \multirow[t]{2}{*}{ Australia } & nights & & & & & & & \\
\hline & $\geq 9$ nights & 50 & 14.4 & $* \$ 1,546$ & $* \$ 1,271$ & $\$ 168$ & $\$ 175$ & $\$ 294$ \\
\hline Number of & 1 & 156 & 44.3 & $* \$ 2,126$ & $* \$ 1,469$ & $\$ 174$ & $\$ 224$ & $* \$ 585$ \\
\hline people & 2 & 73 & 20.7 & $* \$ 1,536$ & $\$ 997$ & $\$ 184$ & $\$ 136$ & $* \$ 299$ \\
\hline spending & 3 & 75 & 21.3 & $* \$ 1,350$ & $* \$ 665$ & $\$ 164$ & $\$ 139$ & $\$ 343$ \\
\hline together & $\geq 4$ & 48 & 13.7 & $* \$ 840$ & $* \$ 522$ & $\$ 188$ & $\$ 146$ & $* \$ 135$ \\
\hline Visitation to & Yes & 223 & 65.6 & $* \$ 1,802$ & $\$ 1,051$ & $* \$ 147$ & $\$ 174$ & $\$ 433$ \\
\hline $\begin{array}{l}\text { other } \\
\text { destinations }\end{array}$ & No & 117 & 34.4 & $* \$ 1,343$ & $\$ 889$ & $* \$ 242$ & $\$ 161$ & $\$ 324$ \\
\hline
\end{tabular}


Table 5

Estimated Regression Model on Total Expenditure

\begin{tabular}{|c|c|c|c|c|c|c|c|c|}
\hline \multicolumn{9}{|c|}{ Estimated Regression Coefficients } \\
\hline \multicolumn{9}{|c|}{ Dependent variable: Natural log total expenditure per person in Australia } \\
\hline \multirow{4}{*}{ Independent variable } & \multirow{2}{*}{\multicolumn{2}{|c|}{$\begin{array}{l}\text { Unstandardize } \\
\text { d coefficients }\end{array}$}} & \multirow{3}{*}{$\begin{array}{l}\text { Standardized } \\
\text { coefficients } \\
\text { Beta }\end{array}$} & \multirow[t]{3}{*}{$\mathrm{t}$} & \multirow[t]{2}{*}{ Sig. } & \multicolumn{2}{|c|}{ Collinearity } & \multirow{3}{*}{$\begin{array}{c}\% \\
\text { impac }\end{array}$} \\
\hline & & & & & & \multicolumn{2}{|c|}{ statistics } & \\
\hline & B & Std. & & & $(p)$ & Tolerance & VIF & \\
\hline & \multicolumn{3}{|c|}{ Error } & & & & & \\
\hline Constant & 7.793 & .479 & & 16.267 & .000 & & & \\
\hline Age: 30 to 49 & .341 & .163 & .164 & 2.099 & .037 & .566 & 1.765 & 38.8 \\
\hline Age: 50 and above & .111 & .246 & .032 & .449 & .654 & .668 & 1.497 & \\
\hline Place of residence: & .222 & .241 & -.083 & .919 & .359 & .420 & 2.381 & \\
\hline \multicolumn{9}{|l|}{ Guangdong } \\
\hline Place of residence: & -.453 & .246 & -.165 & -1.840 & .067 & .432 & 2.317 & -38.3 \\
\hline \multicolumn{9}{|l|}{ Beijing } \\
\hline Place of residence: & -.152 & .229 & -.065 & -.664 & .508 & .361 & 2.770 & \\
\hline \multicolumn{9}{|l|}{ Shanghai } \\
\hline Place of residence: & -.237 & .221 & -.109 & -1.072 & .285 & .336 & 2.975 & \\
\hline \multicolumn{9}{|l|}{ Other } \\
\hline Visiting another & .218 & .130 & .104 & 1.681 & .094 & .905 & 1.105 & 23.3 \\
\hline \multicolumn{9}{|l|}{ destination } \\
\hline 6 nights and under & -.334 & .187 & -.165 & -1.792 & .075 & .410 & 2.441 & -29.6 \\
\hline 7 to 8 nights & .363 & .199 & .166 & 1.826 & .069 & .420 & 2.384 & 40.9 \\
\hline Income: $\leq ¥ 100,000$ & -.468 & .181 & -.231 & -2.584 & .010 & .431 & 2.318 & -38.4 \\
\hline Income: $¥ 100,001$ - & -.364 & .178 & -.166 & -2.042 & .042 & .526 & 1.903 & -31.6 \\
\hline \multicolumn{9}{|l|}{$¥ 300,000$} \\
\hline Overall satisfaction & .003 & .097 & .002 & .035 & .972 & .893 & 1.119 & \\
\hline Travel party size & -.333 & .060 & -.353 & -5.584 & .000 & .866 & 1.155 & \\
\hline \multicolumn{9}{|c|}{ Model Summary } \\
\hline R Square & \multicolumn{3}{|c|}{ Adjusted R Square } & \multicolumn{5}{|c|}{ ANOVA } \\
\hline .299 & \multicolumn{3}{|c|}{.254} & \multicolumn{5}{|c|}{$F(12,203)=6.621 p=.000$} \\
\hline
\end{tabular}


Table 6

ANOVA Results for Overall Satisfaction

\begin{tabular}{|c|c|c|c|c|c|}
\hline \multirow{2}{*}{ Expenditure } & \multirow{2}{*}{$\begin{array}{l}\text { Overall } \\
\text { satisfaction }\end{array}$} & \multirow{2}{*}{ Mean } & \multirow{2}{*}{$\begin{array}{l}\text { Std. } \\
\text { error }\end{array}$} & \multicolumn{2}{|c|}{$\begin{array}{l}\text { ANOVA } \\
\text { results }\end{array}$} \\
\hline & & & & $\mathrm{F}$ & $\begin{array}{l}\text { Sig. } \\
\text { (p) }\end{array}$ \\
\hline \multirow[t]{3}{*}{ Total } & Neutral & $\$ 2086$ & $\$ 354$ & 5.649 & .004 \\
\hline & Satisfied & $\$ 1642$ & $\$ 149$ & & \\
\hline & Strongly satisfied & $\$ 890$ & $\$ 149$ & & \\
\hline
\end{tabular}

Note: Expenditures are in Australian dollars. 
Table 7

ANOVA Results for Satisfaction with Shopping

\begin{tabular}{llllll}
\hline Expenditure & Satisfaction with & Mean & Std. & \multicolumn{2}{c}{ ANOVA results } \\
\cline { 5 - 6 } & shopping & & error & & Sig. \\
& & & & $\mathrm{F}$ & $(p)$ \\
\hline Shopping & Strongly dissatisfied & $\$ 1,394$ & $\$ 468$ & 4.257 & .002 \\
& Dissatisfied & $\$ 619$ & $\$ 117$ & & \\
& Neutral & $\$ 815$ & $\$ 109$ & \\
& Satisfied & $\$ 1,416$ & $\$ 175$ & & \\
& Strongly satisfied & $\$ 921$ & $\$ 239$ & & \\
& & & & & \\
\end{tabular}

Note: Expenditures are in Australian dollars. 
Table 8

Summary Table of the Effects of Socio-demographics and Trip Characteristics

\begin{tabular}{|c|c|c|c|c|c|}
\hline Variable Expenditure & Total & Shopping & $\begin{array}{l}\text { Cultural/ } \\
\text { sporting } \\
\text { activities }\end{array}$ & $\begin{array}{l}\text { Food/ } \\
\text { drinks }\end{array}$ & $\begin{array}{c}\text { Gambling/ } \\
\text { entertainment }\end{array}$ \\
\hline Income & $\sqrt{ }$ & $\mathrm{X}$ & $\sqrt{ }$ & $\mathrm{X}$ & $\mathrm{X}$ \\
\hline Gender & $x$ & $x$ & $x$ & $x$ & $x$ \\
\hline Age & $\sqrt{ }$ & $x$ & $x$ & $x$ & $x$ \\
\hline Dependent child & $x$ & $x$ & $x$ & $x$ & $\sqrt{ }$ \\
\hline Place of residence & $\sqrt{ }$ & $x$ & $x$ & $\mathrm{x}$ & $\mathrm{x}$ \\
\hline Occupation & $x$ & $\sqrt{ }$ & $x$ & $\sqrt{ }$ & $x$ \\
\hline Marital status & $x$ & $x$ & $x$ & $x$ & $x$ \\
\hline Level of education & $x$ & $x$ & $x$ & $x$ & $\sqrt{ }$ \\
\hline Travel party size & $\sqrt{ }$ & $\sqrt{ }$ & $x$ & $x$ & $\sqrt{ }$ \\
\hline Length of stay & $\sqrt{ }$ & $\sqrt{ }$ & $x$ & $\sqrt{ }$ & $\sqrt{ }$ \\
\hline First/repeat visit & $x$ & $x$ & $x$ & $x$ & $\sqrt{ }$ \\
\hline Visiting other destination(s) & $\sqrt{ }$ & $x$ & $\sqrt{ }$ & $x$ & $x$ \\
\hline Satisfaction & $\sqrt{ }$ & $\sqrt{ }$ & -- & -- & -- \\
\hline
\end{tabular}

